\title{
Publications AND Book Reviews
}

J. F. Coakley, The Typography of Syriac: A Historical Catalogue of Printing Types, 1537-1958 (New Castle, DE, and London: Oak Knoll Press and the British Library, 2006). Pp. xxxiv + 272. ISBN: 1-58456-192-0

\section{CARL W. GRIFFIN, BRIGHAM YOUNG UNIVERSITY}

Typography, in general, is the art of printing, but it may refer more specifically to the craft of typeface design, as it does here. Many catalogs and histories of the typography of the Latin script have been written, but much rarer are studies of non-Western typefaces and typography. J.F. Coakley's The Typography of Syriac: A Historical Catalogue of Printing Types, 1537-1958, is exceptional both for its subject matter and its exhaustive character. It is similar to John $\mathrm{H}$. Bowman's Greek Printing Types in Britain (1998), but where Bowman covers just a century and a half of Greek typography ${ }^{1}$ in one region, Coakley treats the entirety of Syriac metal type design and usage.

Coakley is uniquely suited to author this work, due both to his affiliation with the Houghton Library in Harvard, with its superb manuscript and typographic collection, and as the typographer for his own Jericho Press, which publishes examples, quite unique in our day, of hand-set Syriac type. But it is his exhaustive research and passion for the subject that has produced such a superlative work.

The book opens with two prefaces, one for students or typography and the other for scholars of Syriac. Addressing syriacists, Coakley first expresses a sentiment I expect many have had. "One of the reasons I was first attracted to Syriac studies, though I was perhaps hardly aware of it then, was aesthetic. The Syriac book-hand is one of the most graceful scripts that has ever been invented, and simply to be able to read and write it oneself was thrilling." While there has been almost nothing published by syriacists on this topic before now, he continues, "Yet I am sure

${ }^{1}$ A subject on which Coakley has also published. See J.F. Coakley, “The Oxford University Press and Robert Proctor's Greek Types," Matrix 13 (1993): 179-89. 
that most of us do have feelings, conscious or sub-conscious, about the script on the page we are looking at, and I hope the readers of the present book will find it satisfying to inform those feelings with some historical information and criticism" (xiii).

An introduction provides a very brief history of Syriac printing $(1-4), 2$ followed by a thorough survey of the Syriac script in its various forms (4-16) and a discussion of the mechanics of designing and producing Syriac metal type (17-24). The author then introduces the scheme of his type catalog (25-26), which groups together all letterpress Syriac typefaces according to script (serto [W], estrangelo [S] and East Syriac [E]) and assigns each an alphanumeric designation based on script-type and chronological order. Thus the familiar Drugulin serto used in Nöldeke's grammar is designated W61, the estrangelo used in Overbeck's Opera selecta is $\mathrm{S} 14$, etc. This referencing system is convenient and also a practical necessity, given the numerous internal references. Following the letterpress type catalog is a history of Syriac mechanical typesetting, i.e., Linotype and Monotype (251-65), and concluding the book is an appendix of "Evidence for types not shown" (266-67) and a general index (268-72).

The heart of the work, then, is an exhaustive catalog of all known letterpress Syriac typefaces (27-250). Each entry his headed by an alphanumeric reference, as just described, the name of the type designer and/or foundry, and the date when the type was struck or when the first example is attested in print. A sample of each typeface and any derivative fonts is reproduced alongside its history and a description of notable facts and features. The author apologizes for presenting his data in prose, rather than in the technical and tabular format of most catalogs (25n82), but Coakley has produced hereby a highly readable narrative work rather than simply a reference tool.

As Coakley says, this books has value for Syriac scholars, apart from any inherent interest they may have in typography, by

2 A fuller history the author has published elsewhere: J.F. Coakley, "Printing in Syriac, 1539-1985," in Eva-Maria Hanebutt-Benz, Dagmar Glaß and Geoffrey Roper, eds., Sprachen des Nahen Ostens und die Drukrevolution: eine interkulturelle Begegnung / Middle Eastern Languages and the Print Revolution: A Cross-cultural Encounter (Westhofen: Skulima, 2002), 93115. 
informing their aesthetic sense of Syriac typefaces "with some historical information and criticism" (xiii). In this digital age, when Syriac scholars not only can but at times must be typographers of their own work, having some knowledge of "good" or "bad" typeface design, and a historical sense of Syriac type usage, is also desirable. In this regard I found interesting, for example, the history of "gothic" serto scripts.

Unlike standard Greek and (Roman) Latin typefaces, Syriac typefaces were from the beginning modeled on Syriac handwriting. It is unusual for Syriac type to be highly stylized in the way Greek and Latin typefaces may be. A striking exception is the serto type produced by Johannes Richter in 1611, a monolinear and eccentric design which strongly departs from handwritten Syriac. The design influenced a large number of subsequent, predominantly German typefaces which Coakley terms "gothic" (49). ${ }^{3}$

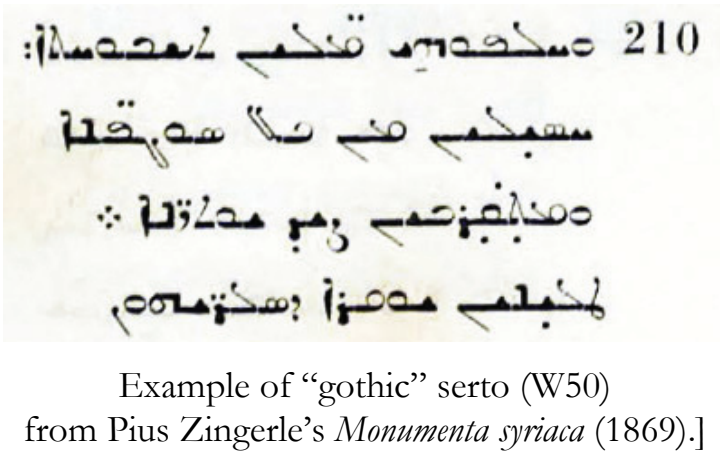

Due to its influence, Richter's typeface has the distinction of marking "the most important step in the degradation of Syriac type-face design in Northern Europe down to the nineteenth century” (49). Peter de Lagarde was even more pointed: „Kein Syrer hat jemals so geschrieben... der verrückteste Syrer in seinen

${ }^{3}$ Gothic type is a class of Latin typefaces which are monolinear, sans serif, and somewhat geometric. Coakley explains alternatively, "Gothic' suggests what is both North European and what is dark and grotesque" (49n65). Gothic types are sometimes also called "grotesques," reportedly because, when first introduced by $19^{\text {th }}$-century advertisers, the public was shocked at their spare and non-traditional character. 
verrücktesten Stunden hat es nicht gethan. “4 While many texts were printed in this typeface up to the twentieth century, it has rightly fallen almost entirely out of use.

Coakley's book is well edited and nicely produced, typeset by the author himself and demonstrating his practical knowledge of the craft. One minor desideratum would be to have the typeface references (W61, S14, etc.) included in the header of the relevant pages, perhaps in square brackets at the inside margin, to facilitate the constant cross-referencing the reader will certainly do. Otherwise, I only find myself wishing the author could have included data he necessarily omits (26), namely, a more full listing of the printers and publications which employed a particular typeface. Coakley includes many such references, and I find this information interesting and valuable. To do this comprehensively would fall outside the scope of a type catalog, certainly, but this catalog thankfully provides future researchers a solid point of departure from which to accomplish that task.

The author rightly titles his work a "Historical Catalogue," and this is certainly a historical work of the first order. While more purely technical data might be tabulated at some future day, or some particular item expanded upon, I cannot imagine this work as a whole being superseded. Such a definitive work requires exceptional labor. The author remarks, "Both of my daughters have been born and have grown up since this project was begun" (xv). The author's long and careful labors are abundantly evident and have resulted in a benchmark work, deserving of our thanks and congratulations.

${ }^{4}$ „Die neuen syrischen Typen des Hauses Drugulin,“ Nachricbten von der Königlichen Gesellschaft der Wissenschaften und der Georg-August-Universität ₹u Göttingen, 1888, no. 14, 377. Cited by Coakley, 49n66. 
Marthe Mahieu-De Praetere, Kurisumala-Francis Mabieu Acharya: a Pioneer of Christian Monasticiam in India (trans.Van Winkle, Susan) Pp. xv + 394, Paperback; a) Cistercian Publications, Kalamazoo, Michigan, 2007, ISBN 978-0-87907-614-6, \$79.95; b) Asian Trading Corporation, Bangalore/ Sopanam, Kottayam, India, 2008, ISBN 81-7086-470-4, IR 200.

\section{BERNARD KILROY, HARTLEY WINTNEY, HOOK, HAMPSHIRE, UK}

The name of Francis Mahieu Acharya (1912-2002) is not new to Hugoye; his work has been praised by both the Director of SEERI (St Ephrem Ecumenical Research Institute, S India) ${ }^{1}$ and Professor Sebastian Brock ${ }^{2}$ who also noted this biography published in its original French in 2001 (without ISBN). However, the English translation now opens up its availability, especially because the Indian edition is at an Indian price.

Abbot Francis's main significance is to have extended the use of Syriac liturgical spirituality in his still living monastery of Kurisumala (S India), including with the first English translation ${ }^{3}$ of the West Syrian Penqitho published by the Dominican Press in Mosul, Iraq 1886-96 as well as a later translation and commentary of the The Ritual of the Clotbing of Monks in the Antiochean Tradition. ${ }^{4}$

Although the biography does not tell us more about the texts, if read selectively it is useful in showing how they came to be created and used in their present liturgical context, which appears to be exceptional.

Francis and his English Benedictine monk collaborator $\mathrm{Fr}$ Bede Griffiths began in 1956 by chanting the Syriac Shbimo Common Prayer (subsequently translated into prose by Bede and

${ }^{1}$ Thekkeparambil, Jacob Hugoye Vol. 5 No. 2, July 2002.

2 Para. 31, 'The Contribution of Departed Syriacists', 1997-2006, Hugoye Vol. 10 No. 1, January 2007.

3 Prayer with the Harp of the Spirit: The prayer of the Asian Churches, Kurisumala Ashram, Vagamon, Kerala 685503 (Nil ISBN); Vol I [Shbimo-Weekday Common Prayer] (1980) $3^{\text {rd }}$ Rev 1983; Vol II [Annunication to Ephipany] (1982) $2^{\text {nd }} \operatorname{Rev} 1999 ;$ Vol III [Fast to Resurrection] (1985) tbp 2008; Vol IV [season of Resurrection to Exaltation of the Cross] 1986. e-mail <kurisumala@yahoo.com>.

${ }_{4}$ Trans. from Book of Priestly Rites (Ktobo d-takse kumroye) Sharfeh, Lebabon, 1952: series Moran Etho 13 (SEERI, Kottayam, 1999). 
later by Francis into rhythmic chant) but found the 'Pampakuda' (Kerala) edition of the Penqitho for Sundays and feast days too abbreviated. In 1961, after unproductive searches in Kerala, he set off on an unyielding hunt in Beirut, Aleppo, Damascus and Jerusalem, nowhere it seems finding the full Syriac Penqitho in or out of use. He finally located it under a layer of dust in a storeroom back in Mosul, Iraq where the new Syrian Catholic Bishop Benni (now Archbishop) was happy to sell him the entire remainder stock of seven sets of seven folio volumes, because (he said) there was no longer any call for it. Neither, nor the biographer either, apparently knew of the parallel interest by Chorepiscopo (later Bishop) Boutros Gemayel of the Maronite Church who published a selective Penqitho translation in French in Beirut during (I surmise) the 1970's, which was translated into English and published in USA during the 1980's. ${ }^{5}$

The Kurisumala English translation is because the Kerala monks, whose mother tongue is Malayalam, use English as a second language because it is the lingua franca of India; learning Syriac proved a real obstacle. Beyond the Syriac text the value has been its spirituality: a) being language of the heart; b) having a breviary not based so exclusively on the Judaic Psalms of the Old Covenant (as in the West) but on hymns and prayers which celebrate the New; c) being more integrated within the 'Economy of Salvation'; d) which in turn is reinforced by the dramatic unfolding of the Syrian Orthodox (or Syro-Malankara in the case of Kurisumala) liturgical calendar.

The systemic inter-connectedness may not emerge through the biography, partly because of Francis' involvement with HinduChristian theology and partly because Francis' pivotal but unpublished Lectionary, which contains the adapted calendar, is not mentioned, though the unpublished Menology with its many Eastern saints is. However, there is ample compensation in the description of the extraordinary love affair which Francis had with

${ }^{5}$ Gemayel, Boutros (Chor-Bishop) Prayer of the Faithful According to the Maronite Liturgical Year, St. Maron Publications, Brooklyn NY, Vol I 1982, Vol II 1983, Vol III 1985, trans. with adaptation from Les Prières des Croyants selon l'Année Liturgique Maronite, Beirut, nd—collated from texts at Bkerke and 'various ancient monasteries'. 
the Eastern Fathers, especially the Syrians, from his first years as a novice Trappist monk in his native Belgium.

The most significant feature of the spirituality of Francis was the steady revelation of an Asian Christ, which displaced for him the classical western versions of the Greco-Roman tradition in which he was brought up. Even though his Asian Christ was an amalgam of Middle East and Indian spirituality, the significance lies in the vibrant originality of his monastic foundation through the use of the Syrian transplant.

Unfortunately the biography does not speculate why the influence of Kurisumala has been limited. It has not been imitated elsewhere and the liturgical office is not used by any other Community (so far as I know) although Francis understandably hoped it would become an adaptable model for the Asian Churches. Although many seminarians and Sisters are sent to Kurisumala for an 'ashram experience' retreat, spontaneous engagement is probably small, including among lay people. For reasons which deserve to be explored, the spirituality of Kurisumala has not enjoyed a fraction of the local appeal of charismatic retreat centres or the cult of Blessed Alphonsa or indeed Pentecostalism.

There are other features which are mentioned only in passing and deserve the future interest of researchers, in particular his translation and use of the Odes of Solomon as a devotional work. Another is an unpublished manual for monk novices on monasticism as a universal phenomenon, from its cradle in ancient India and through its apparently spontaneous apparition in Palestine, in parallel to Egyptian monasticism, and subsequent flowering in Europe.

Some scholars may object to the Penqitho translation because a) it is of two major Hours only (Ramsho and Lilyo); b) it inserts some foreign feast days with new text; c) a few psalms and prayers are trimmed; d) for the sake of rhythm it may depart from the literal Syriac. All true. In addition, Volume I, the Shhimo, incorporates some Indian scriptures. Francis (and others) would answer that there is no such thing as an authoritative text because in the West Syrian tradition each monastery varied and adapted; what matters is the core of living and authentic spirituality. 
Sebastian P. Brock \& George A. Kiraz, Ephrem the Syrian Select Poems Vocalized Syriac text with English translation, introduction, and notes. Provo, Utah: Brigham Young University 2006 xvi + 279 pp. \$39.95. ISBN-13: 978-0-934893-65-7, ISBN-10: 0-934893-65-9.

\section{Paul S. Russell, St. Joseph of Arimathea Anglican THeOlogical COLlege, Berkeley}

Students and teachers of Greek and Latin have long had a wide array of tools to assist them in learning the languages and literatures of their area of study. Original language texts with notes, vocabularies and commentary abound and are pitched at every level of expertise from the beginner to the professional scholar. Students of Biblical Hebrew and New Testament Greek have many helps in their tasks, as well, in the form of vocabularies and readers, though their field still is more likely to expect its students to be involved in professional training and so does not offer the same array of help on varied levels. How far from this has been the plight of the student of Syriac!

In response to this gap in the materials for the study of Syriac, Sebastian Brock and George Kiraz have published a volume that offers students of Syriac language and literature (and their teachers) an entry into the study of the poetry of St. Ephrem the Syrian as well as a doorway into the whole exciting field of Syriac Studies.

The volume contains a brief introduction offering an overview of St. Ephrem's life and work, the transmission of his texts and the meters in which they are composed. Then follow 20 texts, facing an English translation, drawn from 11 of the collections in which the works come down to us. The texts are ordered "according to the outline of Ephrem's concept of salvation history", which allows the volume to teach its readers another important fact about Ephrem: that his many and varied works were all pieces in a delicately drawn picture of reality that is not always in step with our own. Cautious instructors will be glad that this choice of a theological ordering will enable them to avoid long and confusing discussions of different modern schemes of dating Ephrem's works and students will benefit by the push to think of Ephrem's words as he would have done. Appendices that contain a listing of the main editions and English translations of Ephrem's works, an index of the Qale according to which the poems are composed and an index of 
Scripture citations in the texts add greatly to the usefulness of the volume for the private owner.

Each of the 20 texts is prefaced by an introduction that helps to situate it in Ephrem's over-all pattern of thought, discusses its particular meter and offers information on where it survives in manuscript collections. Scriptural citations and allusions are noted in the margin of the translation page and occasional footnotes discuss obscure points and situate the reader in Ephrem's large corpus by drawing connections that only very wide knowledge of Ephrem's work allows. An added voice comes from Andrew Palmer, who has offered a number of contributions to the notes that are marked with his initials.

Many students of Semitic languages who have also worked in Latin and Greek find it difficult to appreciate the reluctance of Semitic scholars to publish critical texts. The long custom of reading the margins and the apparatus at the foot of the page along with the base text seems one that could well be dispensed with. This volume takes a step in that direction by moving the authors' suggested readings into the main text. This makes the experience of struggling through the text much more encouraging for the student. The words he labors to read actually make sense and can be construed successfully. Every beginning student in Semitics knows the bitter moment of realization that one has forgotten to replace a corrupted reading with one drawn from a better text and hidden in the apparatus, out of sight and out of mind. That may become less frequent if this volume's example is more widely followed.

What does this volume offer an instructor in search of a text for a class in Syriac or a student looking for something to read to polish his Syriac skills? The Syriac text is printed in a beautiful, cleanly designed serto script that has been fully vocalized. The lines are well laid out on the pages with ample space between them, an encouragement to reading aloud or study. These practical details make using this volume an exercise in language study for the student rather than a drudgery of deciphering smeared and cramped lettering. The translation tracks with the Syriac line by line, so each pair of pages can be viewed on its own. The notes, which are not found on every page, offer a variety of kinds of help. Some seem designed to aid in teaching critical reading. Note 5 on page 227, attached to stanza 2 of the first of the Carmina Nisibena, is 
an excellent example. The translation offered on the page above is "the deadly flood". The note offers five other possibilities, including two different emendations. An energetic instructor could use this note to devote a good portion of a class meeting to approaches to analyzing the text one sees on the page and how to draw meaning from an idiom very different from modern English.

The primary task of those teaching Syriac studies (as opposed to those pursuing research in the field) is always to draw more students into the area by showing them how fascinating and rewarding it can be. Drs. Brock and Kiraz offer support to that endeavor in more than one way. This volume allows for an engagement with the original text of a great early Syrian theologian and poet. It helps the reader gain a sense of Ephrem's theological vision of the rise of sin and working out of salvation in the world. It demonstrates Ephrem's use of Scripture in his writing. An interested reader, innocent of Syriac, who read the English pages of the book from beginning to end would learn a great deal of theology, some history and gain a sense of a new voice from the Christian past. I think that groups of interested lay Christians could make very successful use of this collection as a selection for their Bible Study or book groups. Individual hymns could certainly be drawn into discussions based outside Syriac Studies. I think this book should be on the shelf of every student of Syriac, but also in parish libraries, as well as college and university collections.

I cannot close without noting, as someone who has been involved in both proof-reading and printing books, that this is an astonishingly elegant and attractive book. I discovered no misprints at all in the course of reading it with quite close attention. Only experience can reveal the amount of effort required to produce such a fine result. I hope that this will be the first of many similar volumes to issue from the Brigham Young University Press. 
Wilhelm Baum and Dietmar W. Winkler. The Church of the East: A Concise History. London and New York: RoutledgeCurzon, 2003, xii + 204 pp; hardcover. $\$ 130$.

\section{JOEL WALKER, UNIVERSITY OF WASHINGTON, DEPARTMENT OF History, SEATTLE}

How does one write a "concise" account of a Church, whose history spans three continents and seventeen centuries? In this learned little survey, Austrian scholars Wilhelm Baum and Dietmar Winkler make a valiant effort to provide an introductory overview to the entire history of the Church of the East. The book is an unrevised English translation of its German original published in $2000 .{ }^{1}$ As such, it fills a conspicuous hole in the English-language historiography, which has not seen a monograph-length survey of the Church of the East since 1929. ${ }^{2}$ The authors composed "with a non-specialist audience in mind"-hence, the absence of footnotes and diacritical marks in transliteration. The results are mixed, though the book offers much of interest for advanced students and serious general readers.

After a sensible introduction to the thorny issue of how to refer to the Church of the East-also known as the Nestorian, the East Syriac, or the Assyrian Church-chapter one explores the origins of Christianity in Iraq and the institutional development of Christianity in the Sasanian Empire (224-642). Winkler (sole author of this section) is perceptive on the development of the East-Syrian patriarchate and theology. The chapter concludes with his spirited defense of the orthodoxy of the East-Syrian creed, which was

1 Wilhelm Baum and Dietmar Winkler, Die Apostolische Kirche des Ostens: Gescbichte der sogenannten Nestorianer (Klagenfurt, Austria: Verlag Kitab, 2000). Winkler is credited with authorship of chapters 1 (on the origins of the Church of the East) and 5 (its modern history), while Baum composed the central three chapters on the Church's history under Islamic rule.

${ }^{2}$ W. A. Wigram, The Assyrians and their Neighbours (London: G. Bell and Sons, 1929; reprint: Piscataway, NJ: Gorgias Press, 2002). The Church of the East does, however, receive extensive coverage in general surveys of Christianity in pre-modern Asia. See esp. Ian Gillman and HansJoachim Klimkeit, Cbristians in Asia before 1500 (Ann Arbor, MI: University of Michigan Press, 1999). 
presented to the Sasanian court in 612 and remains valid for the "entire" Church of the East today.

Chapters two and three survey the Church of the East's history under Arab and then Mongol rule, emphasizing its international and multi-ethnic character extending across large stretches of Asia. Baum briefly describes the patriarchate of Ishoyabh III (580-658) and the East-Syrian monastic movement, which led to the foundation of more than one hundred forty monasteries whose locations have been determined in Mesopotamia, western Iran, and the Persian Gulf. Baum also highlights the well-documented role of East-Syrian doctors and philosophers in the intellectual accomplishments of the Abbasid translation movement. But his chief interest - and arguably the most important contribution of this book-lies in the story of the Church of East's vigorous expansion into Central Asia, China, and southern India. Baum devotes particular attention to the conditions that facilitated the translation of Syriac Christian texts into Sogdian, Uighur, and Chinese. In doing so, he offers valuable context for understanding the famous bilingual Chinese and Syriac stele erected at Xi'an in northern China in 781 and dedicated to a priest from Balkh (Afghanistan). A Buddhist document of the same decade describes, for instance, how an Indian scholar translated texts from Uighur with the help of a "Persian" Christian monk named King-tsing (Adam), who was already renowned for his translations into Chinese.

Baum's account juxtaposes archaeological evidence from across Asia, introducing documents preserved in a wide array of languages and formats. A page from the ninth or tenth-century Sogdian lectionary found at Bulayiq, north of the Turfan oasis in northwestern China, belongs to the detritus of the trilingual monastic library excavated there by the German Theodor Bartus in 1904. Hundreds of Syriac fragments from the same excavation still await publication more than a century later. Baum occasionally taps into documentary sources in non-Christian languages. In a series of copper plates inscribed in Tamil, a regional king of ninth-century south India guarantees the privileges of the Christian merchants of Kerala. But the relationship between these documents and the subsequent development of Malayalam-speaking Christianity in the same region remains frustratingly obscure. The contours of the Church become a bit clearer in the Mongol period, where Baum's narrative leads the reader through whole clusters of new literary 
and documentary sources in Syriac, Armenian, Latin, Persian, and Chinese. The wealth of information crammed into these chapters can be disorienting, but it also serves to underscore the need for new in-depth studies of particular segments in the pre-modern religious history of Asia.

The book's fourth chapter investigates the growing turmoil of East-Syrian communities under Ottoman rule, as papal emissaries negotiated with the two (and often three) patriarchates of the Church of the East based in northern Mesopotamia. The tangled ecclesiastical history of this period unfolds against the backdrop of the competing patriarchal sees at Diyarbakir, the monastery of Rabban Hormizd near Nineveh, and in the highlands of Kochanes on the upper reaches of the Great Zab River. The chapter has much less to say about the social and cultural history of the Church under Ottoman rule. The German original arrived too late to take advantage of David Wilmshurst's massive catalogue of East-Syrian colophons, the majority of them dating to the Ottoman period. ${ }^{3}$ The recent work of Heleen Murre-van den Berg brilliantly illustrates how such colophons can be used to write the social history of this period. ${ }^{4}$ One hopes that future surveys will also be able to integrate the evidence of later Aramaic literature by writers such as the poet Israel of Alqos (†1632).

The latter half of chapter four and chapter five survey the multi-faceted relations between the Christians of northern Mesopotamia and various scholars, diplomats, and missionaries from Europe, Russia, and America. Baum's account offers a refreshingly European perspective on these contacts. His list of characters includes: Anna Hafner Forneris, an Austrian who traveled from Tbilisi to Tabriz in 1830 and left a scandalized description of a drunken Eucharist among the "mountain Nestorians;" the great Orientalist Edward Sachau, who transported more than 250 Syriac manuscripts back to Berlin in 1880; and the popular novelist Karl May (d. 1912), who provided generations of German readers with an image of the region's Christians as a noble

3 David Wilmshurst, The Ecclesiastical Organization of the Church of the East, 1318-1913. CSCO 582; Subsidia 104 (Louvain: Peeters, 2004).

${ }^{4}$ Heleen Murre-van den Berg, "Generous Women in the Church of the East between 1550 and 1850." Hugoye: Journal of Syriac Studies vol. 7, no. 1 (January, 2004): 1-57. 
but endangered people. In Durch das wilde Kurdistan, published in 1892, May describes the region's Christians as "the remnants of the once so powerful Assyrian people, [who] see the sword of the Turks and the dagger of the Kurds hanging forever over them and have endured in more recent times atrocities which would make your hair stand on end" (131). Winkler's account of the fate of those "Nestorians" before, during, and in the wake of the First World War offers a sobering narrative of persecution, combat, flight, starvation, and broken diplomatic promises. ${ }^{5}$ The last portion of chapter five traces the history of the Church of the East to the end of the twentieth century, sketching the formation of the North American and European Diaspora and the growth of ecumenical dialogue. Chapter six gives a very brief overview of the Church of the East's literature preserved in Syriac and other languages.

In sum, Baum and Winkler's survey constitutes a welcome addition to the growing literature on Christianity in pre-modern Asia. The text is probably too dense with names and details to be effective for the "non-specialist" readers named as its target audience. It is also prohibitively expensive. But research libraries should certainly include the title on their shelves. Sixteen illustrations and two maps complement and enhance the text. The sixteen-page bibliography, organized by chapter, provides a valuable guide to further reading and is particularly strong on German-language scholarship that is often overlooked in North American publications. Few bibliographies are without blemishes, but the book's hefty price tag should have paid for better copy-editing. ${ }^{6}$

${ }^{5}$ On these same themes, see now John Joseph's The Modern Assyrians of the Middle East: Encounters with Western Christian missions, archaeologists, and colonial powers (Leiden, Boston, and Cologne: Brill, 2000), 106-73.

${ }^{6} \mathrm{I}$ list a few examples. The bibliographic citation for Samuel Moffett, A History of Christianity in Asia: Volume I: Beginnings to 1500 (Mary Knoll, NY: Orbis Books, 1998) has mistakes in author's name, the book's title, and its publication information. E.A.W. Budge translated rather than edited The Monks of Kublai Khan (London: Religious Tract Society, 1928), although the publication includes a facsimile of the Syriac manuscript. Jean-Maurice Fiey attacked the credibility of the Chronique d'Arbèles, and the volume and pagination for The Chronicle of Séert and several other primary texts are incomplete. These and other mistakes could be easily corrected if there is a second edition. 
Andrzej Uciecha, Ascetyczna nauka w" "Mowach" Afrahata [= Ascetic teaching in Aphrahat's "Expositions"], (Studia i Materialy Wydzialu Teologicznego Uniwesytetu Slaskiego w Katowicach, Nr 3), Katowice: Ksiegarnia Sw. Jacka, 2002, 192 pp.

\section{Witold WitakowsKi, INSTITUTE OF LiNGUistics AND PHILOLOgY, UPPSALA UNIVERSITY, SWEDEN}

The present book is a doctoral dissertation written and defended at the Theological Faculty of the Academy of Catholic Theology (now: Catholic University of Stefan Wyszynski) in Warsaw in 2001. The author is a Catholic priest who is now working at the Theological Faculty of the Silesian University at Katowice in Southern Poland. The book is written in Polish, which is to be regretted, as all the potential readers in Poland would be able to read English, German or French, while few such readers abroad are able to read Polish. There is however a Summary in English (pp. 186-192).

Aphrahat (ca. 270-ca. 345), called "The Persian Sage", is one of the earliest Syriac Church Fathers, which is perhaps the reason for his never-ceasing popularity among the Syriac scholars. His work "Expositions", or "Demonstrations" (Syr. Tahwayāthā), contains 23 homilies or treatises, of which the first 22 begin with the letters of the Syriac alphabet in order. U. renders the title in Polish with the word "Momy"-'speeches', which seems too general. 'Homilie' or 'wyklady' might have been a better choice.

The "Expositions" make up one of the most famous Syriac compositions. They have been translated into German (twice: 1888 by Bert, 1991 by Bruns), Latin (1894-1907, Parisot), English (1869 Gwynn, 1971 Neusner, both partial) and French (1988-89 Pierre), an honour that few Syriac compositions share. The popularity of the "Expositions" is, however, nothing new, as already in Late Antiquity and Middle Ages they were translated (at least partially) into Armenian and Ethiopic (although in both languages they are attributed to Jacob of Nisibis), furthermore into Georgian (attr. to Hippolytus) and Arabic (attr. to Ephrem).

The work of Aphrahat bears witness to early Syriac theological thought at a time when it had still been little influenced by Western, i.e. Greek, theology (the Church of the East accepted Nicea as late as 410 A.D., at the synod of Catholicos Ishaq) and has been the object of lively discussion. In particular the character of 
the "proto-monasticism", to which the so-called "covenanters" devoted themselves, has attracted several scholars since the discovery of Aphrahat's homilies in the middle of the $19^{\text {th }}$ century. It is known that these were ascetics, but the exact kind of asceticism they were devoted to is uncertain. The term in question,

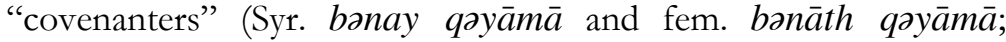
U. neither uses schwa, nor does he mark spirantization of the beghadhkephath consonants), changed its meaning several times, so that that the meaning found in the text of the sixth century'monks'-has hardly any bearing on its semantic value in Aphrahat's writings.

To render the term banay qayāmā $\mathrm{U}$. uses the expression synowie praymierza-'the sons of the covenant'. This translation should be avoided in English as it is unnecessarily literal and in point of fact incomprehensible (notwithstanding the fact that it has been used by some scholars), just as the Syriac expression bar (sing. of banay) taläthìn šanìn, meaning 'a person thirty years old', would be incomprehensible if rendered verbatim: 'the son of thirty years'. It is, however, not easy to provide an adequate and meaningful Polish translation of the term in question: perhaps 'sprzymierzeniec' or 'sprzymierzony' would fit, despite some connotations which the Syriac term may lack.

In addition to an introduction and a conclusion U.'s book contains four chapters. In the introduction U. sketches the development of Aphrahat's studies, showing his acquaintance with the abundant literature on "the Persian sage". This literature is to a high degree coextensive with studies on the intricate problem of the charcter of the "covenanters", the topic which is dealt with in chapter 1 , section 1 . Here $\mathrm{U}$. examines other terms which were used interchangeably with that of bənay qayāma an analysis which allows him to get a better grasp of the meaning of the term in question. These terms are īhìdhāy $\bar{a}$-'single', qaddiš $\bar{a}$-'celibate, continent', bəthū $\bar{l} \bar{a}$ - 'virgin (masc.)'-all of them unequivocally pointing to celibacy - and brnay ' $\bar{e}(d) t t \bar{a}$ - 'the children of the church', which poses the problem of their place within the church and of their relation to the regular faithful.

The chapter as a whole is devoted to the historical context of Aphrahat's ascetic teaching, and since this context is not limited to the milieu of the Christian banay qayāmāa, also non-Orthodox (Markionites) and non-Christian (Manichaean, Gnostic, Jewish) 
ascetic traditions are presented, similar phenomena occurring in these. Aphrahat himself, although conscious of close parallels between his Christian ascetic teaching and those of the "heretics", dismissed any such parallels using the argument of theological context: it is not ascetic practice in itself which leads to salvation, but the context of the faith: if your belief is "wrong" your ascetic practice will not help you (p. 53). Of interest is his polemic against the Jews to whom the ideal of celibacy was contradictory to God's command in Genesis 9,18. Aphrahat first rejected the Jewish opposition, caused, according to him, by the lasciviousness $(p a h \underline{z} \bar{u} t h \bar{a})$ and licensiousness (șahnūthā) of the Jews (Exp. 18,1), but went on to explain that God's intention was not a large quantity of progeny, but its quality, while the ideal of sexual abstinence was not unknown to many Old Testament figures (pp. 58-59).

In chapter 2, entitled "Anthropological elements in the ascetic teaching of Aphrahat", U. analyses a number of notions such as

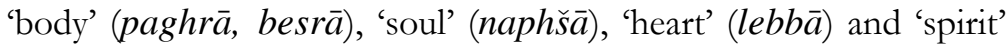
$(r \bar{u} h \bar{a})$, and their role for ascetics. Also women are treated here: they are an impediment in the ascetics' path to achieving perfection or, in other words, the tool of the Devil. This anti-feminist attitude (Exp. 6,3 is a veritable hymn of misogyny!) is only weakly mitigated by his providing some positive female examples from the Old Testament (p. 97), which U., correctly, does not highlight.

Chapter 3 is devoted to the theological dimension of asceticism in the eyes of Aphrahat. Here the most important factors are Christological. For an ascetic Christ provides a model as the conqueror of Satan and death, as a model of humanity and as an $\bar{i} h \bar{i} d h \bar{a} y \bar{a}$, although the term as applied to Christ does not mean 'solitary' but 'unigenitus'. Two subsequent sections in the same chapter take up pneumatological and eschatological aspects.

In chaper 4 U. resumes the topic of the "covenanters", this time taking up their ascetic ideals. He analyses notions such as 'athle teta - which in addition to the original meaning of 'a champion' acquires in the context discussed the meaning of 'a spiritual athlete', i.e. 'an ascetic', 'akhsenya -i.e. keeping distance from the world (also known as nukhrāyūth $\bar{a}$-'being a stranger' scil. to the world), a distance involving liberation from things material. Other ideals of the "covenanters" are the vita angelica, i.e. continuous vigilance (scil. against the deceits of Satan), sexual 
purity; and finally an imitatio Christi, in prayer, in separation from the world, and even in suffering.

All the assertions are supported by abundant text samples taken from the Expositions. These are provided in as many as three forms: the Syriac vocalised text, a transcription (in footnotes), and a Polish translation. The latter wherever I checked is good. What is a bit odd is the presence of transcription and its rules. Since the Syriac text is printed vocalised I see no point in providing a transliteration, for it is a conventional rendering of the script, not of a pronunciation that $\mathrm{U}$. gives here. It is the more surprising that the convention he uses is difficult, at least for the present reviewer, to accept.

Transcription of $\bar{\imath} h \bar{l} d \bar{a} y a$, i.e. with short last $-a$ (on p. 28 twice, p. 29 and 31) may be regarded as a typing error (multiplied by computer 'copy' function), but the use of the short $-e$ (without 'alaph) in plural ending of nouns is met with systematically. This is not a good transcription rule because Classical Syriac does not have short vowels in open syllables. On the other hand one finds on p. 47 , footnote $110, n e s ̌ b u q q$, i.e. a long vowel, where one should have a short one (and in Classical Syriac -o-, not - $u$-). Traditionally in transcribing Semitic languages macrons are used as marks of the length of vowels, no matter what signs (matres lectionis or vowels) are used in the original script, whereas in order to note the presence of matres lectionis the circumflex signs are employed.

To what further unfortunate consequences U.'s transliteration system leads can also be seen in (for example) footnote 109, where we find marqyun, which renders the name 'Markion': a simple -Owould suffice. Even more strange is walentināws in the same footnote. U. follows the unfortunate vocalisation provided by Jean Parisot in his edition in Patrologia Syriaca. This was printed in the Serto writng, whose vocalisation is far from adequate where texts in early Classical Syriac are concerned. In the ending of Valentinos' name, Parisot printed zəqāphā over - $n$ - and then waw (and semkath). He almost certainly pronounced zəqāphà as 'o', and thus this vowel sign only provided the pronunciation already indicated by waw as a mater lectionis, namely the vowel 'o', and not the consonant 'w'. (Incidentally, such vocalisation: zəqāph $\bar{a}$ and waw, would never be used in a real Syriac manuscript). It seems that Parisot used $z \partial q \bar{a} p h \bar{a}$ as other editors of Syriac texts would use a dot over waw, i.e. just to mark its being pronounced as 'o' (and not 'u'). Thus to 
transliterate the ending in question as $-\bar{a} w s$ is, to say the least, confusing.

Another example of this inadequate convention in which U. unfortunately follows Parisot can be found in ${ }^{\mathrm{c}} i d t \bar{a}$ (p. 31, last two lines). This is a typical Western Syriac pronunciation, which does not apply in the case of a writer of the $4^{\text {th }}$ century, who would have used the Classical Syriac pronunciation ${ }^{\mathrm{C}} \bar{e}(d) t t \bar{a}$. On the next page, first line, we find ${ }^{\mathrm{c}} i d t \bar{a} d a^{\circ} l a h a$ instead of $d-\left({ }^{\circ}\right) a l l a \bar{h} \bar{a}$. It is to be regretted that $U$. has not marked the reduplication of the consonants, a feature so characteristic of Classical Syriac, as opposed to Late Western Classical Syriac, the so-called Kthobonoyo. But, again, Aphrahat lived in the fourth century, not in the epoch of, say, Bar'Ebroyo.

The last example of an unfortunate vocalisation, although one which has nothing to do with Classical vs. post-Classical Syriac problems, is met with on p. 28, 14: wan (the name of the sixth consonant in Syriac alphabet). Neither in Polish pronunciation nor in English (and even less so in French) makes such spelling any sense.

Some minor lapses in other areas than transcription can be found too, as for instance taking Manichaeans and Valentinians for "heretics" (p. 41), or attributing the authorship of some "Chronicles" (p. 24) to Isaac of Niniveh.

As to the scholarly literarature taken into account, although this is quite extensive, the author missed Robert Murray's Symbols of Church and Kingdom, Cambridge 1975, which deals inter alia with Aphrahat and which has already become a classic (2nd ed. publ. by Gorgias Press, Piscataway 2004). For works more directly relevant for U.'s topic perhaps the most conspicuous omission is the work of Shafiq AbouZayd, Ihidayutha: a study of the life of singleness in the Syrian Orient: from Ignatius of Antioch to Chalcedon 452 A.D., Oxford: ARAM Society for Syro-Mesopotamian Studies, 1993. AbouZayd devotes a whole chapter to "Aphrahat and the covenanters" (pp. 51-106), and some of his analyses are on precisely the notions dealt with by U. Another work of some importance for the theme of U.'s dissertation is Michael Breydy's, 'Les laïcs et les Bnay Qyomo dans l'ancienne tradition de l'Église Syrienne', Kanon, 3 (1977), pp. 51-75. When referring to K. Brockelmann's Lexicon Syriacum (in a footnote and in the bibliography) U. says "b.m.w." (Polish sine loco). This is strange, since both the original edition 
(1928) and the reprint (1992), at least in my copy, provide the place of publication: Halis Saxonum (= Halle am Saale).

All the remarks above should not, however, be taken as strongly critical of the book under review. It has the merit of providing an in-depth study of the intricate topic of Aphrahat's asceting teaching. For Polish readers U.'s book will make useful reading on the topic, and it is in fact the first of its kind in Polish. The work is a sign that Syriac studies in Poland have gathered momentum. 